\title{
Representation of Women on the Board of Directors under the Companies Act, 2013
}

\author{
Vaibhavi Tadwalkar* and Soundarya Lahari Vedula ${ }^{\dagger}$
}

\begin{abstract}
In this article, the researcher examines the significant provisions that are incorporated into the Companies Act of 2013 to deal with the conventional underrepresentation of women in the corporate arena. The researcher conducts an in depth study of the proviso to section 149(1) of Companies Act of 2013 which mandates the inclusion of atleast one woman director on the Board of Directors and its relevance in ensuring fair standards of corporate governance in every prescribed class of companies. This paper also demonstrates the need for this provision by analysing the position enjoyed by women under the erstwhile legislation i.e. Companies Act, 1956 and by examining the similar legislations enforced in other jurisdictions. Conclusions have been derived from statistical studies in this regard. The reader is also appraised of the effects of non compliance to this provision and the possibilities of its abuse before concluding that the aforementioned law is a prudent parliamentary intervention to enhance the contribution of women towards the development of the country.
\end{abstract}

Keywords: Board of Directors, Companies Act, 2013, Comparative Study, Corporate Governance, Woman Director.

*Second year, BA LLB, National Law Institute University, Bhopal; tadwalkar.vaibhavi@gmail.com

†Second year, BA LLB, National Law Institute University, Bhopal; sndlahari@yahoo.com 


\section{Introduction}

The conventional Indian society constantly prevented women from entering the public domain and they were given an inferior position in the society. The life of an Indian woman was like a well defined masterplan. ${ }^{1}$ Gender bias, which is a result of illiteracy and absolute insensitivity in a predominantly patriarchal society, together with the sheer convenience of male supremacy, always ensured that the condition of women, even among the sophisticated, remained pitiable. ${ }^{2}$ One causative factor of women's unequal status was their absence from leadership positions. ${ }^{3}$ Though women continue to support men and the society in their advancement and progress in every vital sphere of the domestic and social life, their own progress has been shackled by the fetters of societal gender bias. ${ }^{4}$ Discrimination on the basis of gender identity consists of distinction, exclusion, constraints or preference based on gender identity, which has the purpose or consequence of impairing equality before the law or equal protection of the laws or the recognition, enjoyment or exercise of fundamental freedoms on an equal basis. 5

\section{The Issue of Gender Bias}

Gender bias by discrimination against women is a problem which haunts our society till date, whether it is in the household or in public sphere. The corporate sector is not an exception to this. ${ }^{6}$

${ }^{1}$ H.L. Kaila, Women, WorK AND Family (Rawat Publications 1st ed. 2005).

2 Id.

3 WOMEN AND LeAdership: THE STATE OF Play AND STRATEGIES FOR CHANGE (Deborah L. Rhode \& Barbara Kellerman eds., Jossey-Bass, $1^{\text {st }}$ ed. 2007).

${ }^{4}$ Kalpana Bardhan, Women: Work, Welfare and Status. Forces of Tradition and Change in India,20(50) ECONPOLITWKLY, $2207-2220$ (Dec. 14, 1985).

${ }^{5}$ National Legal Services Authority v. Union of India and Ors. (2014) 5 S.C.C. 538, available at http:/ / supremecourtofindia.nic.in/ outtoday/wc40012.pdf , 19 (2014).

6 Dr. E. Raju, Gender Discrimination in India, 2(5) IOSR J. E. F. 55, 55-65 (2014). 
Even though the Indian Constitution enshrines the equality in public employment, this is hardly followed in the corporate sector. The laws which govern our corporate sector seldom give women the required resources to realize their full potential. A superficial look at the list of top executives in the Indian companies by itself could suggest the strong bias against women. Keeping them contented with soft jobs by giving them uncomplicated tasks seems to be the broad opinion in companies. ${ }^{7}$

It seems relatively difficult for women to work their way to the top of the corporate ladder, i.e. to the board of directors (the Board). ${ }^{8}$ Even if women are accepted to the top positions, the unattractive side of the corporate world is palpably seen. Various recorded incidents show that though women directors are initially welcomed with grandeur, when they actively start voicing their opinion and participating in the discussions, they are made to understand that their role is just a governance requirement and that they have a mere signatory authority. ${ }^{9}$

Women have played a key role in the rapid economic and social development worldwide though they remain largely unrecognized. In a study conducted on gender disparity, ${ }^{10}$ India was ranked 101 out of 136 countries in the world. However, lately, due to profound

7 Siri Terjesen, Ruth Sealy \& Val Singh, Women Directors on Corporate Boards: A Review and Research Agenda, 17(3) CORPORATE GOVERNANCE: AN INTERNATIONAL REVIEW,320-337, (2009).

8 David A. Matsa \& Amalia R. Miller, A Female Style in Corporate Leadership? Evidence from Quotas, 5(3) AM. ECON. J. APPL. ECON.136-169 (Jul. 2013), available https:/ / www.google.co.in/url?sa=t\&rct=j\&q=\&esrc=s\&source=web\&cd $=4 \&$ ved $=0 \mathrm{CDMQFjAD \& url}=\mathrm{http} \% 3 \mathrm{~A} \% 2 \mathrm{~F} \% 2 \mathrm{Fwww}$.iza.org $\% 2 \mathrm{Fconferen}$ ce_files\%2FLeadership_2012\%2Fmiller_a7875.pdf\&ei=o5uuVJa1M8uSu ATrl4CABA\&usg=AFQjCNGXWdYFfX5z79wg2eytCj73EO-6IQ.

${ }^{9}$ Deepika Nath, Gently Shattering the Glass Ceiling: Experiences of Indian Women Managers, 15(1) WOMEN IN MANAGEMENT REVIEW, 44-52 (2000), available

http://www.emeraldinsight.com/doi/pdfplus/10.1108/0964942001031 0191.

10 World Economic Forum, The Global Gender Gap Report, 2013, http://www3.weforum.org/docs/WEF_GenderGap_Report_2013.pdf (last visited on Jan. 07, 2015). 
changes in the status of women, there has been a significant transformation in the attitude of the society towards women employment. Many successful women have finally been able to prove their mettle by achieving high ranked positions in some of the most renowned corporations. On an average, women in India make up to $50 \%$ of the workplace but account for less than $4 \%$ of top executives of the nations. ${ }^{11}$

\section{Women on the Board of Directors: The Indian Perspective}

In India, the Companies Act, 1956 was the most important piece of legislation that empowered the central government to regulate the formation, financing, functioning and winding up of companies. The Companies Act, 1956 was repealed in 2013 giving way to the new Companies Act, 2013 which inter alia contains the mechanism regarding organizational, financial, managerial and all the relevant aspects of a company and empowers the Central Government with certain powers to regulate the companies and their working. ${ }^{12} \mathrm{One}$ significant departure of the new Act from the old one is the provision for mandatory inclusion of atleast one woman on the Board of Directors in certain class or classes of companies. The effectiveness of the provisions in the new Act depends on their effective enforcement.

Section 149(1) of the Companies Act, $2013^{13}$ provides that every listed public company shall have at least one third of the total number of directors as independent directors. It says-

1) Every company shall have a Board of Directors consisting of individuals as directors and shall have:

a. a minimum number of three directors in the case of a public company, two directors in the case of a private company, and one director in the case of a One Person Company; and

${ }^{11}$ KAILA, supra note 1.

${ }^{12}$ A. RAmaiya, A.RAmaiyA's Guide to the Companies Act (LexisNexis Butterworths 17th ed. 2010).

13 The Companies Act, 2013, § 149 (1). 
b. a maximum of fifteen directors:

Provided that a company may appoint more than fifteen directors after passing a special resolution:

Provided further that such class or classes of companies as may be prescribed shall have at least one woman director.

Thus, the second proviso to section 149(1) provides that a class or classes of companies shall appoint minimum one woman director on its Board. The said class or classes of people are explained in rule 3(i) of the Companies (Appointment and Qualifications of Directors) Rules, 2014.

According to this rule every listed company shall appoint at least one woman director within one year from the commencement of the second proviso to section 149(1) of the Act. Every public company other than the listed companies, having a paid up share capital of Rs. 100 crore or more or turnover of Rs. 300 crore or more as on the last date of latest audited financial statements, shall also appoint at least one woman director within one year from the commencement of second proviso to section 149(1) of the Act. ${ }^{14}$

A period of six months from the date of the company's incorporation has been provided to enable the companies incorporated under Companies Act, 2013 to comply with this requirement. Existing companies (registered under the previous Companies Act) have to comply with the above requirements within one year. Further, if there is any intermittent vacancy of a woman director, then, it shall be filled up by the Board within three months from the date of such vacancy or not later than the immediate next board meeting, whichever is later.

This provision has been inserted in order to ensure that women get the suitable opportunities to be appointed as directors in the company and to ensure gender diversity in the Board. The need for introducing this important provision was felt due to the

\footnotetext{
14The Companies (Appointment and Qualification of Directors) Amendment Rules, 2014, available at http://www.mca.gov.in/Ministry/pdf/NCA_Rules_18092014.pdf (last visited on Jan. 08, 2015).
} 
underrepresentation of women at the senior executive level in the corporate world.

\section{Gender Diversity and Gender Equality}

In an ideal situation, gender diversity would occur as women scale up the corporate hierarchies just like her male counterparts and graduate to the board through her sheer knowledge and achievements. Since that has not happened, these ratios need to be forced into a new configuration at the workplace in the interest of the enterprise. 15

Gender equality includes protection from sexual harassment and right to work with dignity, which is a universally recognized basic human right. ${ }^{16}$ Based on the guidelines issued by the Supreme Court in Vishaka Case, ${ }^{17}$ the Sexual Harassment of Women (Prevention, Prohibition and Redressal) Act, 2013 was enacted in order to protect women from any kind of sexual harassment at their workplace. The Act mandates the constitution of a Complaints Committee, which should be headed by a senior level woman employee and atleast half the members of such a committee should be women. ${ }^{18}$ The presence of a woman on the board of directors would certainly impede the creation of a hostile environment in the company.

The concept of glass ceiling also has to be taken into consideration at this juncture. The popular notion of glass ceiling effects implies that gender disadvantages are stronger at the top of the hierarchy than at the lower levels and that these disadvantages become worse later in a person's career. ${ }^{19}$ It is a specific type of gender or racial

${ }^{15}$ Robert Jensen, Beyond Race, Gender, and Class: Reclaiming the Radical Roots of Social Justice Movements, 12(2) GLOBAL DiALOGUE 1 (2010), available at http://uts.cc.utexas.edu/ rjensen/freelance/beyondracegenderandclas s.htm.

16Vishaka \& Ors. v. State of Rajasthan \& Ors., A.I.R. 1997 S.C. 3011, 3016. ${ }^{17} I d$.

18 The Sexual Harassment of Women (Prevention, Prohibition and Redressal) Act, 2013 §§ 4(2)(a) \& 4(2)(c) proviso.

${ }^{19}$ David A. Cotter, Joan M.Hermsen, Seth Ovadia\& Reeve Vanneman, The Glass Ceiling Effect 80(2) THE UnIVERSITY OF NORTH CAROLINA PRESS 655, 
inequality which refers to artificial and unseen barriers to the advancement of women and minorities and reflects discrimination between those who prosper and those left behind. ${ }^{20}$

In India, a shortage of qualified and experienced women at executive levels is often given as one of the main reasons for male domination in the Boards. The different social hindrances that Indian women have to overcome to commence a career reveal why the prospect of having a truly diverse boardroom has never before seemed too plausible. ${ }^{21}$ Many of the women who sit on boards are referred to as survivors. ${ }^{22}$

A study conducted in 2013 by the McKinsey \& Company had ranked India as second last with respect to representation of women on corporate Boards ${ }^{23}$. The findings of a survey conducted by India Inc., regarding employment discrimination also reveals that only $1 \%$ of the CEOs in Indian Companies are women and

655-682 (2001), available at

http://www.vanneman.umd.edu/papers/CotterHOV01.pdf.

${ }^{20}$ U.S. Glass Ceiling Commission, Good for Business: Making Full Use of the Nation's Human Capital (Mar. 1, 1995) http:/ / digitalcommons.ilr.cornell.edu/cgi/viewcontent.cgi?article=1118 \&context=key_workplace.

${ }^{21}$ Meenu Goyal\& Jai Parkash, Women Entrepreneurship In India-Problems And Prospects 1(5) INTERNATIONAL JOURNAL OF MULTIDISCIPLINARY RESEARCH (Sep. 2011), available at http://zenithresearch.org.in/images/stories/pdf/2011/Sep/14.Vol_01_ Issue_05\%20MEENU\%20GOYAL\%20women\%20paper.pdf.

${ }^{22}$ Deborah J. MCLAUghlin, RunNing IN High HeEls: HOW TO LEAD WITH INFLUENCE, IMPACT \& INGENUITY (Lisa Canfield ed., Balboa Press 1st ed. 2014).

${ }^{23}$ McKinsey \& Company, Women Matter 2013 - Gender Diversity in Top Management: Moving Corporate Culture, Moving Boundaries, Nov., 2013, at $8, \quad$ available at http://www.mckinsey.com/ /media/mckinsey/dotcom/homepage/2 012_March_Women_Matter/PDF/WomenMatter\%202013\%20Report.as hx. 
only 465 out of the 9000 board members in 1500 companies analyzed by them were women. ${ }^{24}$

In order to ensure the compliance of the provision in the new Companies Act, it should be strictly enforced. However, the liability for noncompliance of this provision can be seen under section 450 of the Companies Act, 2013 which enshrines that:

If a company or any officer of a company or any other person contravenes any of the provisions of this Act or the rules made there under, or any condition, limitation or restriction subject to which any approval, sanction, consent, confirmation, recognition, direction or exemption in relation to any matter has been accorded, given or granted, and for which no penalty or punishment is provided elsewhere in this Act, the company and every officer of the company who is in default or such other person shall be punishable with fine which may extend to ten thousand rupees, and where the contravention is continuing one, with a further fine which may extend to one thousand rupees for every day after the first during which the contravention continues.

Thus it can be seen that, there is no specific and harsh punishment for non compliance of this provision under the Companies Act, 2013. However, along with the provisions of the Companies Act, 2013 the companies to be listed under the Securities and Exchange Board of India (SEBI) also have to comply with the provisions of Clause 49 of the Equity Listing Agreement. ${ }^{25}$

Through a circular dated April 17, 2014, the SEBI released the amendments to Clause 49 of the Equity Listing Agreement, which

${ }^{24}$ Ambreen Wani, Breaking Through The Glass Ceiling, 2 INTERNATIONAL MONTHLY REFEREED JOURNAL OF RESEARCH IN MANAGEMENT AND TECHNOLOGY79, 79-88 (2013).

${ }^{25}$ Securities and Exchange Board of India, Circular, CIR/CFD/POLICY CELL/2/2014,

http:/ / www.sebi.gov.in/cms/sebi_data/attachdocs/1397734478112.pdf (last visited Jan. 08, 2015). 
clarified that the provisions regarding the appointment of a woman director shall be applicable with effect from April 01, 2015. ${ }^{26}$ The revised Clause 49 updates and aligns the Listing Agreement with the changes brought out in corporate governance in the Companies Act, 2013. The amended Clause 49 of the Listing Agreement includes the Composition of the Board of Directors under which, it is mandatory to have atleast one woman director. ${ }^{27}$ The noncompliance of any of the clauses of the Listing Agreement would result in disciplinary actions against the company which may include suspension or delisting of the securities. ${ }^{28}$

\section{Representation of Women on Board of Directors in Other Jurisdictions}

Different world jurisdictions have ensured the presence of women in their company boardrooms by enacting suitable and strict legislations. For example, Norway, in 2003 became the first country in the world to enforce a gender quota requiring nearly 500 firms including 175 firms listed on the Oslo Stock Exchange to raise the proportion of women on their Boards to $40 \%$. Though initially the compliance of this provision was voluntary, in 2006 the Norwegian Parliament made it mandatory thereby imposing a final shut down as a penalty for the noncompliance of the law, by January 1, 2008. Thus Norway has imposed a gender quota requirement for corporate board membership in all public limited liability companies. ${ }^{29}$ In a period of ten years, the women representation in Norwegian company boards has shot up from $7 \%$ to $41 \%$.

${ }^{26}$ Securities and Exchange Board of India, Circular, CIR/CFD/POLICY CELL/7/2014,http://www.sebi.gov.in/cms/sebi_data/attachdocs/141 0777212906.pdf (last visited Jan. 08, 2015).

${ }^{27}$ Indian Boards Database, Corporate Governance, http://indianboards.com/files/clause_49.pdf (last visited Jan. 08, 2015).

${ }^{28}$ Securities and Exchange Board of India, Memorandum to the Board,http://www.sebi.gov.in/boardmeetings/132/issueofcapital.pdf (last visited Jan. 07, 2015).

${ }^{29}$ Aagoth Storvik\& Mari Teigen, Women on Board: The Norwegian Experience, FRIEDRICH EBERT STIFTUNG, Jun. 2010, at 4, available athttp://library.fes.de/pdf-files/id/ipa/07309.pdf. 
Various other countries have followed the lead of Norway. In 2010, France made $40 \%$ reservation for women on boards compulsory for its largest companies, whether listed or not the breach of which would cause for the suspension of the director's fees. A recent survey reveals that France now has $29.7 \%$ women directors in their companies. ${ }^{30}$

Italy introduced a similar legislation in 2011 which requires public limited companies and state owned companies to have atleast 33\% of each gender on their boards (Executives and Non Executives) by 2015 (with a target of $20 \%$ for the transitional period). In the event of non compliance, a progressive warning system was developed which would eventually lead to the dissolution of the Board. ${ }^{31}$ This resulted in an increase in the number of women directors to $23.6 \%$ from 2003 to 2013. In 2014, Italy had 25.8\% women directors. 32

The European Commission has also taken steps to break the glass ceiling that continues to bar female talent from reaching top positions in Europe's biggest companies. On the basis of equal qualification, priority shall be given to the underrepresented women community. The Commission had proposed a legislation in 2013 , with the aim of attaining a $40 \%$ representation for women in non executive board member positions in publicly listed companies, with the exception of small and medium enterprises. The objective of attaining at least $40 \%$ membership for the women community in the non executive positions has to be met by

\footnotetext{
${ }^{30}$ Press Release, Khaitan \& Co \& Biz Divas, Women on Boards: A Policy, Process and Implementation Roadmap (Aug. 07, 2014) http:/ /www.bizdivas.in/wpcontent/uploads/2014/09/women_on_boardV3-PRINT.pdf.

${ }^{31}$ European Commission, National Factsheet Gender Balance in Boards,http:/ / ec.europa.eu/justice/genderequality/files/womenonboards/womenonboards-factsheet-it_en.pdf (last visited Jan., 2013).

${ }^{32}$ Corporate Women Directors International, 2014 CWDI Report- Women Board Directors of Fortune Global 200 -2004-2014,(Jul. 2014),https:/ / enterprisingwomen.com/the-connector/2014-cwdireport-women-board-directors-of-fortune-global-200-2004-2014.html.
} 
2020 while public undertakings have the time until 2018.33 This proposal has been voted in favour of and is under consideration by the European Parliament since 2013.

On the other hand, the United States of America has no quota requirement at the federal level and still has $22.5 \%$ women directors. ${ }^{34}$ The California Senate, in 2013, approved a resolution formally encouraging gender diversity, which urges every Californian public company to have one to three women on its Board of Directors by the end of 2016, depending on the size of the Board. 35 The United Kingdom also has a fair women representation in its Boards without any quota. However, developed Asian countries like China and Japan have only $8.4 \%$ and $2 \%$ of women representation respectively in the boardrooms, and have no quota requirement on the Boards, suggesting that no change can occur unless sought for. ${ }^{36}$

The Corporate Women Directors International, reports that the firms in countries with a quota in place have $24 \%$ of their Board seats held by women in comparison to $17.8 \%$ for those companies based in countries where no such quota exists. ${ }^{37}$ This supports and strengthens the argument for having a fixed quota in the Board for representation of women.

The significance of having women in such decisive positions cannot be understated. According to Zia Mody, Managing Partner, AZB \& Partners, "women have more patience, a higher emotional quotient, stated willingness to learn rather than 'pretend to know it all' and

${ }^{33}$ Press Release, European Commission, Women On Boards: Commission Proposes 40\% Objective (Nov. 14, 2012) http://europa.eu/rapid/pressrelease_IP-12-1205_en.htm.

${ }^{34}$ Khaitan, supra note 30.

${ }^{35}$ David A. Katz, Wachtell, Lipton, Rosen \& Katz, Developments Regarding Gender Diversity on Public Boards, THE HARVARD LAW SCHOOL FORUM ON CORPORATE GOVERNANCE AND FinANCIAL REGUlATION(Nov. 12, 2013) http:/ / blogs.law.harvard.edu/corpgov/2013/11/12/developmentsregarding-gender-diversity-on-public-boards/

${ }^{36}$ Corporate Women Directors International, supra note 32.

${ }^{37}$ Christine Naschberger, Women Company Directors: Can Quotas Change The Status Quo, (Sep. 10, 2014) http://forbesindia.com/ printcontent/38551. 
they are more inclusive". ${ }^{38}$ Women have a mellowing effect on driving board consensus and fostering innovation. ${ }^{39}$ Ensuring the presence of women at the higher executive positions adds new perspectives to the discussions and further paves the way for increasing female leadership across all levels.

Many studies show that companies with women on their Board of Directors show better profitability, are more likely to have healthy and productive board meetings and are less likely to have cases of fraud. A 2007 study by Mckinsey on the largest European companies found that those companies with atleast three women on their executive committees significantly outperformed their competitors in terms of average return on equity by about $10 \%$ while operating profit was nearly twice as high. ${ }^{40}$ This shows that women have a positive effect on the functioning and management of the affairs of the companies. A 2011 survey by a nonprofit organization 'Catalyst' based in the United States also showed that company Boards made up of $19 \%$ to $44 \%$ women achieved $26 \%$ more return on invested capital than those firms with no women directors. ${ }^{41}$

${ }^{38}$ Philip Ljee, Rica Bhattacharyya \& Kala Vijayaraghavan, How Women Have to Work Harder and Smarter To Claim Their Rightful Space on Indian Corporate Boards, ECONOMIC TIMES BUREAU(Jul. 29, 2014) http:/ / articles.economictimes.indiatimes.com/2014-07-

29/news/52186665_1_women-directors-woman-director-professionalwomen.

${ }^{39}$ Deloitte, Women In The Boardroom: A Global Perspective, (3rd ed. Mar. 2013) available

http:/ / www2.deloitte.com/content/dam/Deloitte/global/Documents/ Risk/gx-ccg-women-in-the-boardroom.pdf.

40 McKinsey \& Company, supra note 23 at 5.

41 Catalyst, Fortune 500 Women Executive Officers and Top Earners, (Dec. 11, 2011),

http:/ / www.catalyst.org/knowledge/2011-catalyst-census-fortune500-women-executive-officers-and-top-earners 


\section{Statistics on the Participation of Women on the Board of Directors in India}

In India, an analysis of Return on Equity (ROE) data of top 100 Indian companies (BSE 100) by Randstad provides that companies with women on their boards have a positive impact on ROE.42 The study reveals that the Board of a private sector company, run by a professional Chief Executive Officer with a mix of both men and women, helped ROE rise by $4.4 \%$. In contrast, a similar company with a Board comprising of only men saw its ROE rise by a mere. $1.8 \%$ in the same period.

However, data on women's participation in top management in India is still dismal. Women are found to hold only $9 \%$ of the total number of Board positions across the companies listed on Bombay Stock Exchange. Another study reveals that only $6 \%$ of the total directors in Indian companies are women. ${ }^{43}$

While this provision introduced under section 149 of the Companies Act, 2013 encourages gender diversity/ representation in the boardroom, it also has some serious lacunae. The primary reason for introducing reservation for women is to ensure their better representation in the corporate sector along with their social upliftment. However, like the 33\% reservation for women in the local self governmental institutions, which brought women into the fore of the political and social domain of India, but made most of them mere puppets in the hands of their male relatives, this quota might also be abused by promoters to ensure the domination and control of their family.

For example, Reliance Industries Limited inducted Nita Ambani, wife of Chairman Mukesh Ambani, as a director and other companies like Godfrey Phillips India (Bina Modi, wife of K.K. Modi), Raymond (Nawaz Gautam Singhania, wife of Gautam

\footnotetext{
${ }^{42}$ Moorthy K. Uppaluri, Empowering women to leadership positions, THE HINDU:

http:/ / www.thehindubusinessline.com/features/newmanager/empow ering-women-to-leadership positions/article6611866.ece (last visited Jan. 08, 2015).

${ }^{43}$ Khaitan, supra note 30.
} 
Singhania), Asian Paints (Amrita Amar Vakil) and Kirloskar Oil Engines (Gauri Kirloskar) also appointed their own family members as directors in order to meet the requirements of the Act. ${ }^{44}$

Another possibility of abuse can arise wherein the promoters might resort to the practice of 'window dressing', in order to comply with the provisions of the Act, if the reservation is made strict and mandatory to all companies. In such a case, a situation similar to Norway might emerge in India. The Norwegian companies, in order to comply with the provisions of reservation promoted many women, with much less experience than their predecessors, to the position of the directors.45If this happens, it would certainly compromise the efficiency and would result in the reduction of the corporate productivity/profits. However, it is too early to reach any conclusion regarding this provision since the data available to establish this is very sparse.

\section{Conclusion}

The provision for women directors to be on corporate Board of Directors in the prescribed class or classes of companies is a progressive step and has set the agenda of gender diversity/ representation in momentum. While the current statistics in India is not very encouraging, a change in the scenario is already seen with the coming into force of the new Act. In four and a half months since the SEBI Board Meeting in February, 2014, 91 women have been appointed to 97 directorship positions in 94 companies (as of June 30, 2014). ${ }^{46}$

\footnotetext{
${ }^{44}$ Press Trust of India, Nita Ambani Becomes First Woman Director on Reliance Board, THE ECONOMIC TIMES, (Jun. 18, 2014), http://articles.economictimes.indiatimes.com/2014-06-

18/news/50678707_1_ril-board-reliance-foundation-p-kkapil;http://archive.financialexpress.com/news/nita-ambani-co-whenlaw-says-bring-women-on-board-companies-look-to-home/1267389.

${ }^{45}$ Rohini Pande \& Deanna Ford, Gender Quotas and Female Leadership: A Review, BACKGROUND PAPER FOR THE WORLD DEVELOPMENT REPORT ON GENDER (Apr. 07, 2011) http://scholar.harvard.edu/files/rpande/ files/ gender_quotas_-_april_2011.pdf.

${ }^{46}$ Khaitan, supra note 30.
} 
In order to ensure good corporate governance, greater women representation is imperative. A positive intervention in the form of the new Companies Act can bring in the desired change. However, for the Act to be a success, the onus of ensuring greater representation for women primarily rests on the board members. It is critical for organizations that need to comply with the Act, to have a clear understanding of the obligations and responsibilities in ensuring compliance with the Act. Developing countries, so far, have had no quota for women representation on the board, with India being the first country with a statutory mandate. India may well be an inspiration for the other developing countries if we are able to demonstrate an actual change in the women representation on the Board as well as influence their presence through senior leadership. 